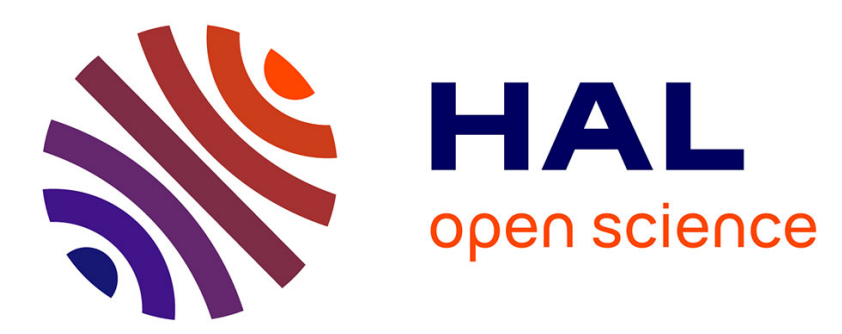

\title{
TBTs, Firm Organization and Labour Structure- The effect of Technical Barriers to Trade on Skills
}

Giorgio Barba Navaretti, Lionel Fontagné, Gianluca Orefice, Giovanni Pica, Anna Cecilia Rosso

\section{- To cite this version:}

Giorgio Barba Navaretti, Lionel Fontagné, Gianluca Orefice, Giovanni Pica, Anna Cecilia Rosso. TBTs, Firm Organization and Labour Structure- The effect of Technical Barriers to Trade on Skills. 2019. hal-02296142

\author{
HAL Id: hal-02296142 \\ https://hal.science/hal-02296142
}

Preprint submitted on 24 Sep 2019

HAL is a multi-disciplinary open access archive for the deposit and dissemination of scientific research documents, whether they are published or not. The documents may come from teaching and research institutions in France or abroad, or from public or private research centers.
L'archive ouverte pluridisciplinaire HAL, est destinée au dépôt et à la diffusion de documents scientifiques de niveau recherche, publiés ou non, émanant des établissements d'enseignement et de recherche français ou étrangers, des laboratoires publics ou privés. 


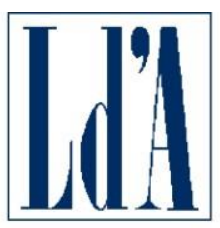

CENTRO STUDI LUCA D'AGLIANO

WWW.DAGLIANO.UNIMI.IT

CENTRO STUDI LUCA D'AGLIANO

DEVELOPMENT STUDIES WORKING PAPERS

N. 453

September 2019

\section{The TBTs, Firm Organization and Labour Structure}

Giorgio Barba Navaretti*

Lionel Fontagné**

Gianluca Orefice***

Giovanni Pica****

Anna Cecilia Rosso*

* Università degli Studi di Milano and LdA

**Paris School of Economics - Universit e Paris I and CEPII

$* * * \mathrm{CEPII}$

**** Università della Svizzera Italiana, LdA and CSEF 


\title{
TBTs, Firm Organization and Labour Structure*
}

\author{
The effect of Technical Barriers to Trade on Skills
}

\author{
Giorgio Barba Navaretti ${ }^{\dagger} \quad$ Lionel Fontagné Gianluca Orefice $^{\S} \quad$ Giovanni Pica \\ Anna Cecilia Rossoll
}

September 12, 2019

\begin{abstract}
Trade shocks in export markets may affect the employment composition and the organization of exporting firms. In particular, the imposition of new technological standards in destination markets may force exporters to adjust the firm's organization to comply and cope with the additional complexity of the new production process. This paper investigates the effects on firms' organization of shocks induced by the introduction of Technical Barriers to Trade (TBTs) in exporting countries. It relies on the Specific Trade Concern (STC) data released by the WTO to identify trade-restrictive TBT measures, combined with matched employer-employee data for the population of French exporters over the period 1995-2010. It also exploits information on the list of product-destinations served by each French exporter. Controlling for tariffs and for a given state of technology in the sector of the firm, it finds that exporters respond to increased complexity associated with restrictive Technical Barriers to Trade at destination by raising the share of managers at the expense of blue collars, white collars and professionals. This paper is related to the growing literature exploring how firms organize production in hierarchies to economize on their use of knowledge. It is also related to the well beaten literature on the labour market effects of trade, but from the perspective of exports rather than imports.
\end{abstract}

Key words: skill composition, labor demand, job polarization, trade barriers

\footnotetext{
${ }^{*}$ We thank Sante De Pinto for excellent research assistance. We are also indebted to the participants of the 2017 Paris Pronto Workshop, and in particular to our discussant Ron Davis. This paper was produced as part of the project "Productivity, Non-Tariff Measures and Openness" (PRONTO) funded by the European Commission under the 7th Framework Programme, Theme SSH.2013.4.3-3 "Untapped Potential for Growth and Employment Reducing the Cost of Non-Tariff Measures in Goods, Services and Investment", Grant agreement No. 613504.

${ }^{\dagger}$ Università degli Studi di Milano and LdA. Email: barba@unimi.it

${ }^{\ddagger}$ Paris School of Economics - Université Paris I and CEPII. Email: lionel.fontagne@univ-paris1.fr

${ }^{\S}$ CEPII. Email: gianluca.orefice@cepii.fr

๑Università della Svizzera Italiana, LdA and CSEF. Email: giovanni.pica@usi.ch

"Università degli Studi di Milano and LdA. Email: anna.rosso@unimi.it
} 


\section{Introduction}

Trade shocks in export markets may affect the employment composition and the organization of exporting firms. In particular, the imposition of new technological standards in destination markets may force exporters to adjust the firm's organization to comply and cope with the additional complexity of the new production process. This paper investigates the effects on firms' organization of shocks induced by the introduction of Technical Barriers to Trade (TBTs) in exporting countries.

Technical Barriers to Trade generally impose technical requirements on exporting firms and raise their fixed costs. In earlier work Fontagné and Orefice (2018) have shown that Technical Barrier to Trade impact mainly the extensive margin of trade for French companies, with a marginal effect on the intensive margin. The same conclusion holds in sector-aggregated estimations. In the framework of trade models with heterogeneous firms (Chaney 2008), this outcome is consistent with an increase in fixed rather than variable export costs, interpreting the imposition of new TBTs as an increase in the fixed cost for the firms. However, little is known on what generates such fixed costs. In what follows, we empirically investigate whether this is due to organizational requirements stemming to overcome Technical Barriers to Trade (TBT).

Organizational requirements may follow from the increasing complexity of tasks associated to TBTs and can be managed vertically, adding hierarchical layers (as in Garicano 2000, Caliendo and Rossi-Hansberg 2012 and Caliendo et al. (2018)), or horizontally, by enlarging layers, especially the top ones, with rising numbers of individuals with similar levels of responsibility, but different areas of competence, knowledge and managerial tasks. We therefore examine whether firms respond to TBTs by increasing managerial complexity through an expansion of the share of managers in total employment; and hence through a reshaping of the organizational pyramid, with managers growing at the expense of less qualified positions, like professionals, white and blue collars. In line with the earlier literature, we also investigate whether firms react to TBTs shocks by increasing the number of organizational layers.

Trade policy has recently undergone profound transformations and provides us with a good laboratory for testing the organizational impact of trade shocks. Multilateral agreements, Preferential Trade Agreements and unilateral episodes of trade liberalization have limited the use of tariff measures as an instrument of trade policy. Therefore, policymakers increasingly resort to TBTs to obstacle trade. While these measures are not explictly aimed at restricting trade, in many instances they do act as effective trade barriers and even respond to reductions in import tariffs (Orefice, 2017; Francois et al. 
2011). One may argue that not all TBTs are restrictive, as they disseminate information on products' characteristics and reduce uncertainty to the benefit of the consumer. However, a subset of TBTs are restrictive enough, and potentially unjustified on safety or other acceptable grounds, such that exporting countries challenge them in dedicated committees at the WTO. These measures are object of Specific Trade Concerns (STCs) in dedicated committee at the WTO.

In the present paper, we exploit the variability of technical barriers to trade over time and their different occurrence in different markets for a given category of products as a trade shock for exporters. Our identification strategy relies on the variation in the exposure of exporters to this kind of restrictive measures on their different markets. We use Specific Trade Concern (STC) data released by the WTO to identify trade-restrictive TBT measures. Such trade obstacles may affect the organization of the firms and its skill composition because they may require exporting firms to change the labor mix to adapt the production and management process to the additional complexity induced by the restrictive TBTs. We observe the year of introduction of the concern at the WTO committee and the duration of the case, at the HS4 product category and destination level. We also observe the product-destination composition of firms exports, hence the firm-level time-varying exposition to stringent TBTs.

To properly identify the organizational effects of such trade obstacles, we need to isolate the impact of TBTs from the impact that other determinants of export behaviour have on the firm-level composition the workforce and on the organization of the firm. So, other trade obstacles, such as transport costs or tariffs at destination, have to be considered and controlled for in the empirical exercise ${ }^{1}$ Beyond trade, we also need to control for technological shocks potentially affecting the within-firm job composition. Our empirical approach relies on the assumption that such technological shifts are sector $\times$ occupation $\times$ time-specific and fully captured by a set of time-varying sector-occupation effects. Finally, unobserved firm-specific characteristics such as productivity, capability to comply with restrictive standards and the composition of hierarchical layers at the time of the shock are additional confounding factors. The panel structure of our data allows us control for the time-invariant component of such unobservable firms characteristics by means of firms $\times$ occupation-specific fixed effects.

The presence of a TBT Specific Trade Concern may be the result of the lobbying activity of a given firm, introducing a potential endogeneity bias in our empirical exercise. This concern is reduced in our study because EU-raised STCs are unlikely to be affected by a specific French firm. However, to further reduce any endogeneity concern (and the issue of the endogenous selection of firms into

\footnotetext{
${ }^{1}$ Of course, the overall demand for labor may shift in reaction to changes in exports. Our analysis is not concerned with the impact of TBTs on the level of employment in exporting firms, but rather on the composition the workforce and on the organizational changes within the firm.
} 
destination markets) we rely here on an Instrumental Variable approach. The presence of a EU-raised TBT Specific Trade Concern is instrumented by the presence of a non-EU raised STC 2

We gather firm-specific information from several individual- and firm-level data sources from France. We measure the composition of the workforce in French firms in terms of professional categories exploiting the DADS (Déclarations Annuelles des Données Sociales), a matched employer-employee large-scale administrative database. The professional categories include managers (further split in several subcategories), professionals, white collars, qualified blue collars and non qualified blue collars $3^{3}$ We also exploit information on the list of product-destinations served by each French exporter over the period 1995-2010 (data Direction Dénérale Des Douanes et Droits Indirects provided by the DGDDI). Finally, we rely on restrictive TBTs as revealed by Specific Trade Concern, at HS 4-digit and by destination, so that for each firm we are able to compute the number of exported varieties (i.e. product-destination combinations) under technical standards that really imply an increase in the cost of exporting due to additional complexity of the firm's process.

Controlling for firm $\times$ occupation-specific time-invariant unobserved heterogeneity, time-varying sector $\times$ occupation shocks, and tariffs at destination, we find that one additional Specific Trade Concern on TBT implies the increase in the firm's share of managers (i.e. the top hierarchical layer). When instrumenting the EU-raised TBTs faced by French firms in a given destination-sector with the TBTs raised by non-EU countries in the same destination-sector to account for residual endogeneity concerns, we find that one additional TBT concern increases the share of managers by 1 percentage points. The average increase in the share of managers in the firm facing a restrictive TBT is matched with a decrease in the share of all other occupational groups (in particular qualified and non-qualified blue collar occupations). Among managers, it is shown that exporters affected by TBTs at destination resort to an increase in the share of salaried head of enterprise, sales executives and engineers. Additionally, we investigate whether the change in the skill composition within the management group happens through an increase in the size of an already existing layer (intensive margin) or through the introduction of new layers (extensive margin). We find that the exporting firms facing TBTs are more likely to add a layer at the level of salaried head of enterprise. These results illustrate how firms respond to the increased complexity caused by more stringent TBTs by raising the proportion of workers employed in managerial positions, the highest hierarchical layer.

This paper bridges together two strands of literature. The first is the growing literature that

\footnotetext{
${ }^{2}$ See section 3.1 for a detailed discussion of all the possible sources of endogeneity and how these are dealt with by our IV approach.

${ }^{3}$ See section 2.2 for detailed description of occupation groups.
} 
explores how firms organize production in hierarchies to economize on their use of knowledge Garicano, 2000: Caliendo and Rossi-Hansberg, 2012) and predicts that firms react to shocks by managing the number of layers in the organization 4 We complement this literature by looking at whether firms respond to technical barriers by increasing managerial complexity through an expansion of the share of managers in total employment, hence through a reshaping of the organizational pyramid, with managers growing at the expense of less qualified positions. Potentially, increasing complexity of knowledge and tasks can be managed vertically, by adding hierarchical layers, or horizontally, by enlarging the span of competences and knowledge across different management units. Accordingly, we also investigate whether firms react to TBTs shocks managing the number of layers.

From a broader perspective, the second strand of literature we touch upon is the one on the labour market consequences of trade. While the early empirical evidence suggested that such effects were small, increasing wage inequality being ascribed to skill-biased technological change, recent evidence has challenged this view. It is now established that, in the US manufacturing sector over the period 1991-2011, local labor markets highly exposed to import competition from China experienced larger job losses than less exposed areas (Acemoglu et al., 2016; Autor et al., 2013). More generally, the polarization of the labor market has been explained by the combination of trade and technological progress (both trade exposure and the share of hours worked in technology-related occupations grew hand in hand implying the difficulty to disentangle their respective responsibilities). Using data on 16 Western European countries, Goos et al. (2014) study the role of offshoring and technological change on the job polarization of EU labor markets over the period 1993-2010. In particular, they show the rise in employment shares for high-paid professionals, managers and low-paid personal service workers; and the contemporaneous fall in the employment share for manufacturing routine office workers. Using matched French employer-employee data from 1994 to 2007, Harrigan et al. (2016) find a polarization particularly detrimental to middle wage occupations. Using matched employer-employee Danish data over the period 1999-2009 Keller and Utar (2016) attribute one sixth of the decline in mid-skills workers employment to the Chinese import competition 5

However, due to the scant of data on firms' employment and workforce composition, no clearcut conclusion emerges from previous literature on the firm's job composition effect of trade shocks. Also, less attention has been paid on the consequences of shocks faced in export (rather than import)

\footnotetext{
${ }^{4}$ Using French data, Caliendo et al. (2015) find evidence that French manufacturing firms grow by actively managing the number of layers in their organization, while Caliendo et al. (2018) find that expanding Portuguese firms add layers of (middle) managers.

${ }^{5}$ Trade shocks may also affect the portfolio composition of exporting firms. This channel as been analysed in Bernard et al., 2011, Mayer et al. 2014, Fontagné et al. 2018).
} 
markets ${ }^{6}$ These two points represent the main contributions of our paper within the broad literature on trade and labour markets.

The paper proceeds as follows. Section 2 describes the data and presents basic descriptive statistics. Section 3 discusses the empirical strategy. Section 4 presents our baseline results, while in section 4.3 we propose an extension by analysing the effect of TBTs on the layers of the firm. Section 5 concludes.

\section{Data description and sample selection}

In this section we present the data employed in our empirical exercise. STC and French Customs data are presented in section 2.1. In section 2.2 we discuss the matched employer-employee data and the workers' occupation classification adopted to define the employment shares by occupation category. In section 2.3 we present some descriptive statistics concerning the presence of TBT barriers.

\subsection{Specific Trade Concerns on TBT}

We use Specific Trade Concern (STC) data released by the WTO to identify trade restrictive Technical Barriers to Trade (TBT) 7 When one or several WTO members raise a concern at the TBT WTO Committee over a non-tariff measure, they specify the country imposing the measure, the product of concern and the objective of the measure concerned 8 All this information is recorded and made available by $\mathrm{WTO} 9$

A collection of all STCs provides a systematic set of all the TBT measures perceived as sizable trade barriers by exporters. Indeed, the measures have to be sufficiently important for exporting countries to raise a "concern" at the WTO. For this reason, we can be fairly sure that our data do identify barriers to trade. This is an important advantage with respect to using other TBTs sources

\footnotetext{
${ }^{6}$ Two exceptions are Bas and Bombarda (2013) and Maurin et al. (2002) who consider the labor market consequences of trade liberalization at destination (but they do not focus on the job composition of firms). Bas and Bombarda (2013) rely on firm level exports data to assess the impact of increased access to the Chinese market. As a result of the combination of market size and increased competition it is shown that lower Chinese import tariffs account for 18 percent of additional French export sales. Maurin et al. (2002) explore the export based channel of the demand for skills. Using French firm level data they show that becoming an exporter requires an investment in development and marketing, hence an upgrade of the skill composition of the firm.

${ }^{7}$ We discard trade concerns raised on Sanitary and Phytosanitary measures (SPSs) for two reasons. First, SPSs are mostly related to the contents of food products (ingredient mix) and do not concern technological and/or technical standard to be complied with (small fixed costs component attached to SPS). Indeed, as showed in Fontagné et al. (2015) the imposition of a new SPS measure implies a mix of variable and fixed costs for the exporting firms. Second, the number of SPS measures faced by French firms steadily increases over time. Thus, any unobserved firm-specific trend differentially affecting the different categories of workers would bias our estimates. See next section for more details on our empirical strategy.

${ }^{8}$ The TBT committee provide to WTO members a forum where discussing issues related to technical measures imposed by other members.

${ }^{9}$ The STC dataset is available at http://www.wto.org/english/res_e/publications_e/wtr12_dataset_e.htm.
} 
based on exhaustive list of measures in place. Indeed other datasets (as TRAINS or Perinorm), by listing all the measures imposed by a country, mix together measures that restrict trade with those that might even increase trade 10 The objective of the present paper is to test whether an increase in the export cost - as revealed by the cost to meet the technical standard at destination - affects the labor composition of workforce.

Overall, the TBT-STCs database contains information respectively on 318 specific trade concerns raised over the period 1995-2011. For each concern, we have information on: (i) the country raising the concern, (ii) the country imposing the measure, (iii) the product codes (HS 4-digit) involved in the concern, (iv) the year in which the concern has been raised to the WTO and (iv) whether it has been resolved and how. So we build a panel dataset tracking the presence of an ongoing STC on TBT for a specific country pair (imposing-complaining country) and product combination over time ${ }^{11}$ Then we disentangle the STCs raised by EU (which are the relevant ones for French firms exports) from those raised by non-EU countries (used as an instrumental variable in what follows). Finally, we collapse this dataset by HS 4-digit, destination and year, keeping the information on whether a given productdestination combination has at least one ongoing STC raised by EU and/or extra-EU member (in a given year). Importantly, concerns are raised, then discussed in the committee, and withdrawn after a while, generally based on a gentleman agreement amending the regulation. Some concerns failed to be fixed, and nevertheless the case may disappear if the exporting country considers that it cannot be solved and that its exporters will adjust and comply. Notice that a concern is considered solved by the WTO if it is not raised in the dedicated TBT committee for two years or more. Then, the date of the last raising at the TBT committee is assumed to be the date of the resolution of the STCs 12

The STC dataset is then used to compute the number of stringent TBTs faced by each French exporter. To this end we matched STC data with French Custom data providing information on the list of product-destination served by a given French exporter over the period 1995-2010 13 For each firm we have information on the export value into a given product-destination. The dataset classifies product categories using Combined Nomenclature at 8 digits (CN8) but it has been aggregated here at HS 4-digit level to be consistent with the STCs dataset. Then we merge individual exports with STCs

\footnotetext{
${ }^{10}$ Technical standards might reveal consumer tastes at destination.

${ }^{11}$ This represents an additional advantage to the use of alternative dataset (e.g. by WITS) who provide only crosssectional information on the presence of TBTs.

${ }^{12}$ The publicly available dataset does not include the year of resolution of STCs. On this respect we benefited from a confidential data by the WTO, in which a STCs on TBT is assumed to be solved if it is not raised in WTO committee for two years or more. The date of the last raising at the TBT committee is assumed to be the date of the resolution of the STCs.

${ }^{13}$ Provided by the DGDDI (Direction Dénérale Des Douanes et Droits Indirects), these data are subject to statistical secrecy and are quasi exhaustive of the universe of French exporters. There is only a declaration threshold of 1000 euros that applies to any extra-EU destinations (for European countries such threshold is higher and around 150000 euros).
} 
by HS 4-digit and destination, so that for each firm we computed the number of exported varieties (i.e. product-destination combinations) affected by a TBT-STC. Each firm has a unique identification code ("SIREN") that allows us to match custom/STC data with DADS data.

\subsection{Matched employer-employee data}

We next measure the composition of the workforce in French exporting firms exploiting the DADS (Déclarations Annuelles des Données Sociales), a matched employer-employee large-scale administrative database. These data are based upon mandatory employer reports of the earnings of each employee subject to French payroll taxes which essentially apply to all employed persons in the economy (including self-employed). Each observation in DADS corresponds to a unique individual-plant combination in a given year, with detailed information about the plant-individual relationship, including the number of days during the calendar year that individual worked in that plant, the (gross and net) wage, the type of occupation (classified according to socio-professional categories), the full time/part time status of the employee. Moreover, it provides the fiscal identifier of the firm that owns the plant, the geographical location of both the employing plant and firm, as well as the industry classification of the activity undertaken by the plant/firm. The data span the 1995-2010 period. Since we are interested in the job composition of firms, we have to disregard micro-firms. For this reason we restrict the analysis to companies having at least 5 employees after removing workers with missing and zero gross wages.

Before moving to the descriptive and econometric evidence, we need to clearly define the occupation groups considered in what follows. Based on the French occupation classification (Catégories Socioprofessionelles, CS 2-digit), we follow Caliendo et al. (2015) and categorize workers on the basis of their hierarchical level in the organization. To this purpose, as shown in Table A1, we define five occupational categories: $(i)$ managers (PCS codes from 21 to 38), (ii); professionals (PCS codes from 42 to 48 ), (iii) white collars (PCS codes from 53 to 56), (iv) qualified blue collars (PCS codes from 62 to 65$),(v)$ non-qualified blue collars (PCS codes from 67 to 69$)$.

\section{$2.3 \quad$ Descriptive statistics}

Figure 1 shows two graphs: the left panel shows the evolution of the total number of destination-HS4 chapter combinations with ongoing STCs on TBTs raised by the EU between 1995 and 2010 14 while

\footnotetext{
${ }^{14}$ The left panel of figure 1 shows only active STCs on TBT. So, when TBT concerns are solved there is a decrease in the number of active TBTs.
} 
Figure 1: TBTs: total and share of exports

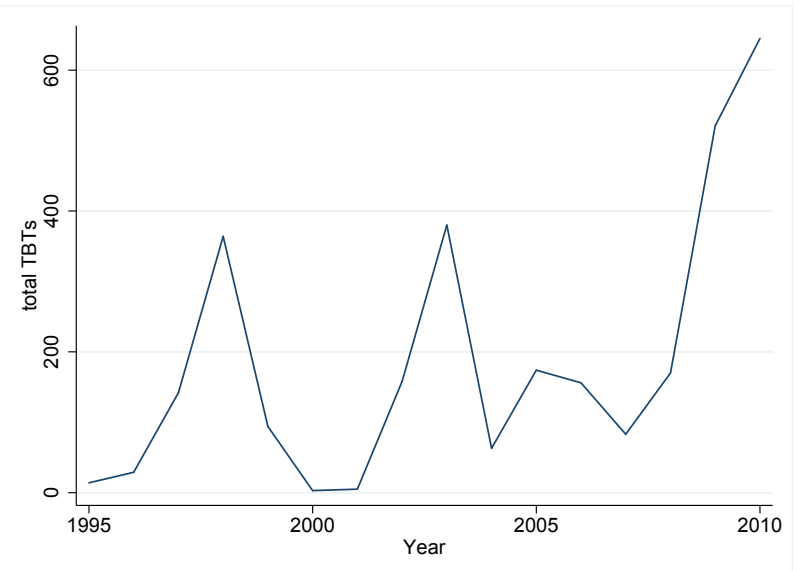

(a) Total Number of TBTs

Note: number of sector-destination pairs under ongoing EU-raised STCs on TBT.

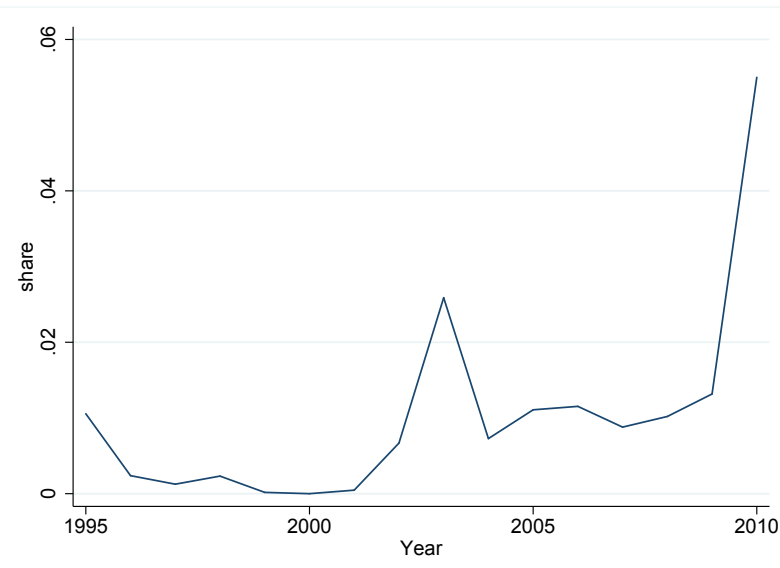

(b) Share of exports with TBTs

Note: share of total exports under sector-destination with ongoing STC on TBT (coverage ratio).

the right panel shows the evolution of the export value of products covered by STCs on TBTs over the total value of export. Both measures are computed on the sample of HS4 and exports of our sample of firms used in the estimation. The number of TBT concerns varies a lot over time, increasing to more than 600 concerns before the year 2000, decreasing to almost zero between 2000 and 2001 and then peaking again in 2003 and in 2009 ${ }^{15}$ The large variation over time (and across products) of STC TBT measures is key for our identification strategy (see next section).

Figure 2 plots the change in the average number of TBTs faced by French firms over the period 1995-2010 (horizontal axis) against the change in the average share of employees by occupation group in each HS 4-digit manufacturing sector (vertical axis). The figure shows that, rising TBTs are associated with an increase in the share of managers (panel 1), and a decrease in the share of whitecollars (panel 3), qualified and non-qualified blue collars (panel 4 and 5). The share of professionals reported in panel 2 seems to be uncorrelated with the change in the number of TBT faced by French firms.

In Table 1 we report some in-sample descriptive statistics. We divide the sample into firms that serve sectors-destinations that have never been affected by Specific Trade Concern (last column of the table), and firms facing at least one TBT between the 1995 and 2010 (i.e. firms facing at least one TBT concern on one of its product-destination markets over the period). Firms experiencing at least one TBT concern face one average 1.76 TBT concerns. The second and third row of Table 1 show the number of firms and the percentage of firms in each column. As expected, firms facing STCs on TBT

\footnotetext{
${ }^{15}$ In 2000-2001 many concerns raised by the EU were resolved. In particular, the sudden reduction in the number of active TBT concerns in 2000-2001 is due to the resolution of two big STCs raised by the EU against measures imposed by Egypt on 219 HS4 chapters and solved in 2000-2001 (see minute G/TBT/Notif.98.206).
} 
Figure 2: TBTs and changes in the within firm employment composition
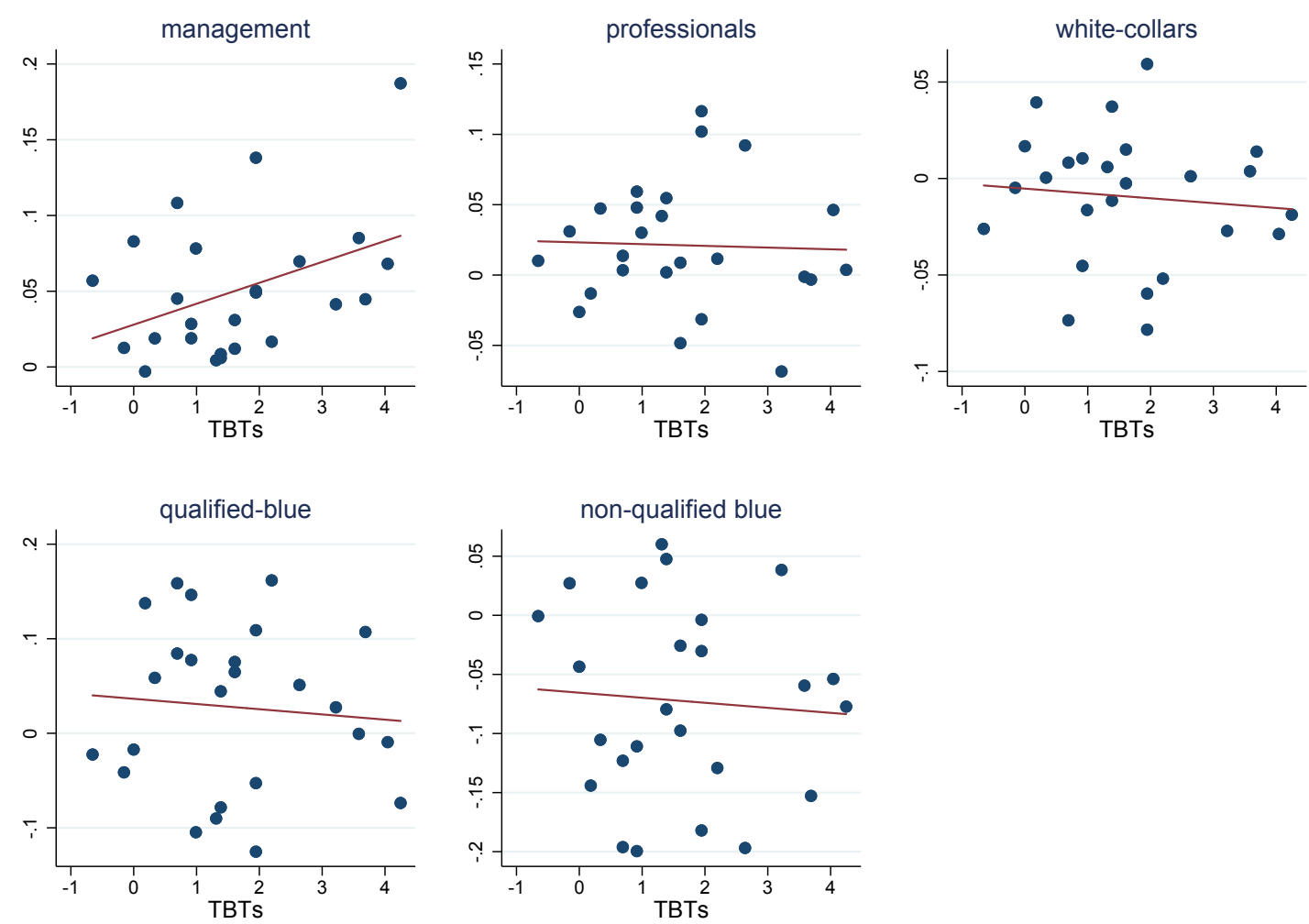

Source: Authors' calculations on DADS, WTO STCs and French Custom data. Note: in the vertical axis we report the change in the average share of employment (by type of occupation) across firms within a HS 4-digit sector. In the horizontal axis we report the change in the average number of TBTs faced by French firms over the period 1995-2010. Each point represents a 4-digit sector. Sectors without TBT or having zero change in TBT are not reported to the sake of readability. 
Table 1: Descriptive Statistics

\begin{tabular}{lcc}
\hline & At least one TBT & TBT-free \\
\hline Average number of TBTs per affected firm & 1.76 & \\
Firm/year observations & 3,271 & 27,506 \\
\% of firms & 11.9 & 88.10 \\
\hline Sectoral distribution (\%) & & \\
Manufacturing of food, beverages and tobacco & 7.03 & 12.91 \\
Manufacturing of of textiles and leather & 13.29 & 24.97 \\
Manufacture of wood, paper, publ./print & 10.33 & 1.7 \\
Chemical products, rubber, metals & 36.63 & 21.64 \\
Machinery and equipment & 10.96 & 10.69 \\
Manufacture of electrical and optical equipment & 11.07 & 20.72 \\
Transport equipment/furniture & 10.69 & 7.37 \\
\hline Occupations (\%) & & \\
Share of managers & 19 & 20.18 \\
Share of professionals & 23.43 & 10.33 \\
Share of white collars & 10.94 & 33.94 \\
Share of qualified blue collars & 29.15 & 21.95 \\
Share of non qualified blue collars & 17.31 & 0.075 \\
\hline Tariff & 0.11 & 9,582 \\
Market distance (km) & 14,574 & 7.87 \\
Number of market served & 22.48 & 17.10 \\
Number of varieties & 75.32 & 3.34 \\
Number of layers (Caliendo et al., 2015) & 3.49 & 161,268 \\
\hline Observations & 5,118 & \\
\hline Soure: DADS, wTO STCs an Fren & & \\
\hline
\end{tabular}

Source: DADS, WTO STCs and French Custom data for 1995 to 2010.

are the minority ( $12 \%$ of the sample). The rest of the table, for the sample of affected and non-affected firms, shows: (i) the sectoral distribution, (ii) the average employment share by macro-occupation, and (iii) the average trade friction (tariff and distance) and export margins. In the last row we also report the average number of layers for the samples of firms.

We observe a total of 30,777 firms: among them, we have 3271 firms affected at least once by a restrictive TBT between 1995 and 2010 ${ }^{16}$ When looking at the sectoral distribution of firms with concerns, as expected, the chemical industry is over-represented in the sample with TBTs. Looking at macro-occupations, the shares of managers and professionals are higher among firms with TBTs, while both the shares of qualified and non-qualified blue collars is lower. In general, firms in the TBT sample are serving relatively more distant destinations and face higher average tariffs than other exporting firms. Interestingly for the econometric exercise reported in section 4.3 , affected and non-affected firms do not differ in terms of average number of layers.

\footnotetext{
${ }^{16}$ Although from French Custom data we observe more than one hundred thousands firms, the sample of firms shrinks considerably because we drop firms with less than 5 employees (as job composition does not make sense for micro-firms), and firms that do not appear in matched employer-employee DADS data (i.e. French exporters that are not obliged to declare their workforce composition).
} 


\section{Empirical strategy}

Our basic empirical specification borrows from Fontagné et al. (2015) with the caveat that the impossibility to attribute workers to the production of a specific good for a specific export destination forces us to work at the firm/year level:

$$
y_{i, t, k}=\alpha_{i, k}+\gamma_{s, t, k}+\beta_{1, k} T B T_{i, t-1}+\beta_{2, k} \operatorname{Tariffs}_{i, t-1}+\varepsilon_{i, t, k}
$$

where $y_{i, t, k}$ is the share of the occupational category $k$ in the employment (total number of workers) of firm $i$ at time $t{ }^{17}$ The term $\alpha_{i, k}$ is a firm $\times$ occupation fixed effect, and $\gamma_{s, t, k}$ is a set of (1-digit) sector $\times$ year dummies specific to occupation $k$. Tariffs $\mathrm{s}_{i, t-1}$ measures the average tariff level faced by each French firm across its exported products and destinations, and aims at isolating the effect of technical barriers to trade from traditional tariffs. Specifically, to each firm we attach the tariff level for a specific product-destination and then take the simple firm specific average tariff across products and destinations.

The variable $T B T_{i, t-1}$ measures the number of Specific Trade Concerns on TBTs faced by the firm $i$ at time $t-1$, measured as the sum of the EU-raised TBT Specific Trade Concerns faced in all the products-markets combinations in which the firm exports ${ }^{18}$ Therefore our coefficient of interest, $\beta_{1, k}$, measures the impact of the number of TBTs faced by the specific firm on the share of workers employed in occupation $k$. Notice that the variable $T B T_{i, t-1}$ varies both when a concern is raised on a market in which the firm is already present, and when the firm enters or exits a market in which a concern exists. This raises an endogeneity concerns which is addressed (and discussed) in the next section. We run the above specification, separately for each occupation $k$, on the full sample of manufacturing exporting firms with more than 5 employees resulting from the merge between Custom and matched employeremployee data (see section 2 for more details on the estimation sample). Results from estimates on these samples are presented in section 4.1

Any time-invariant firm-specific factors - including average productivity and average firm size affecting the share of workers employed in occupation $k$ is controlled by the occupation-specific firm fixed effect $\alpha_{i, k}$. Firm fixed effects also control for the average size of the firm. This is particularly relevant in our empirical strategy because large firms may export (on average) towards a wider set of destinations and thus face more TBT measures. The use of a within estimator reduces reverse causality

\footnotetext{
${ }^{17}$ Occupation groups are defined in section $\sqrt{2.2}$.

${ }^{18}$ We keep the number of TBTs at $t-1$ as we assume that any adjustment in the workforce composition of firms takes some time to happen. By taking the lagged number of concerns faced by the firm reduces also the reverse causality issue.
} 
concerns, as any reverse causality argument must be valid in deviations from the occupation-specific firm average (rather than in levels) - see next section for more detailed discussion. In all specifications we always include (1-digit) sector-year dummies specific to occupation $k$ controlling for any sectortime-occupation specific factor affecting the workforce composition of French firms. Our main objective here, as said above, is to control for the technological shocks to occupation $k$ common to all firms in a given sector. Indeed, unobserved sector specific demand shocks may require an adjustment in the composition of the workforce of firms operating in the sector and will be controlled by the fixed effect $\gamma_{s, t, k}$. Moreover, any time-varying firm-specific shock that affects homogeneously all the workers' categories of the firm - i.e. that affects the employment level - is mechanically controlled for by having the share of a given worker category over total employment as dependent variable.

Even though our rich specification allays concerns of reverse causality, as it is unlikely that the devation from the firm's average in a specific occupation share of a single French firm affects the imposition of a TBT at destination, there may be a remaining endogeneity concern to address, as discussed in the next section. For this reason, we propose a 2SLS approach to address any remaining endogeneity concern.

\section{$3.1 \quad$ Endogeneity}

As discussed above, the rich set of fixed effects $\alpha_{i, k}$ and $\gamma_{s, t, k}$ considerably reduces endogeneity concerns. By adopting a within estimator, any reverse causality concerns are strongly reduced as they must be valid in deviation from the firm's average (i.e. deviations from the average firm's skill composition affecting the change in the number of TBTs in sector $s$ at time $t$ ). However, one may still worry about the residual endogeneity of TBTs if unobserved HS 4-digit specific shocks (as opposed to shocks at the 1-digit sector level controlled for by $\gamma_{s, t, k}$ ) affect both the workforce composition of firms and the probability of observing a TBT at destination (omitted variable). Also, without an instrumental variable approach, we risk not disentangling the effect that comes from an exogenous change in the number of TBTs faced by a given firm, and the endogenous firm's entry decision: following a positive productivity shock, a firm can enter a given product-destination market with a TBT and thus facing endogenously additional TBT measures (selection bias) ${ }^{19}$ A last endogeneity concern comes from the political economy of Specific Trade Concerns, as they may results from the lobbying activity of big

\footnotetext{
${ }^{19}$ Another source of bias stems from the relationship between productivity and skill intensity at the firm level. More productive firms might, at the same time, bear the cost of entering (or staying into) more difficult markets (affected by TBT concerns) and employ a higher share of skilled workers. This might lead to the fallacious conclusion that firms coping with stringent TBTs adjust by upgrading the skill composition of their workforce. Insofar as the source of unobserved firm-level heterogeneity is time-invariant, this concern is fully addressed by the use of firm $\times$ occupation fixed-effects.
} 
French firms at the EU commission. For the reasons discussed above, we complement the fixed effects specification with an IV strategy.

In building the IV for TBTs we benefit from the rich information contained in the STC data. As an instrumental variable for the EU-raised TBT faced by French firms in a given destination-sector, we use the STCs raised by non-EU countries in the same destination-sector. We instrument our main dependent variable, i.e. the number of concerns raised by the EU, with the number of concerns raised by the rest of the world (extra-EU) on the same product-destination combinations. In the literature, the rationale for this IV is that concerns raised by non-EU countries cannot be affected by the lobbying power of any French firm that could eventually request the imposition of a TBT at destination. More formally, the identification assumption is that TBT concerns raised by non-EU countries are orthogonal any firm-level shocks to the workforce composition of a specific French firm, conditioning on firm and sector-by-year effects specific to occupation $k$. Under this (untestable) assumption, we are able to capture the exogenous variation of the EU-TBTs that is not due to time-varying firm-level shocks and we are therefore able to identify the causal effect of TBTs on the composition of the workforce of French firms.

As widely recognized in the previous literature, also tariffs cannot be considered as purely exogenous in a firm-specific regression if firms may have sufficient lobbying power to influence the trade policy of the country (EU in this case). For this reason, we instrument also the average tariffs faced by the specific French firm to further reduce any remaining endogeneity concern. The IV for tariff is based on the tariff level faced by extra-EU countries in exporting toward a given destination-sector market. For each destination $j$ and sector $s$ we calculate the average import tariff imposed towards extra-EU exporting countries $\left(\operatorname{Tariffs}_{s, j}^{n o n-E U}\right)$. We instrument the firm's average tariff using the average tariff imposed by firm's destinations towards non-EU exporters:

$$
\operatorname{Tariffs}_{i, t-1}^{I V}=\frac{1}{S} \frac{1}{J} \sum_{s j} \operatorname{Tariffs}_{s, j, t-1}^{n o n-E U}
$$

where $S$ and $J$ represent respectively for total number of sectors $s$ and destination $j$ served by firm $i$ at time $t-1$. We run the IV specification, separately for each occupation $k$, on the full sample of exporting manufacturing firms as described in section 2. results from estimates on these samples are presented in section 4.1 


\section{Results}

\subsection{The effect of TBTs on layers size (intensive margin)}

We estimate equation (1) on all manufacturing companies that have exported at least once between 1995 and 2010, therefore using a sample of over 30,000 manufacturing companies. Table ?? reports results from separate regressions of equation (1) for each occupational category. In particular, we look at the effect of TBT on the share of managers, professionals, white collars, qualified and non-qualified blue collars in the firm's total workforce. The first column shows the fixed effect estimation, while the second column shows the results from the IV estimation, where both technical barriers to trade and tariffs are instrumented as explained in the previous section. The dependent variable is the share of full-time equivalent employees in occupation $k$ over the total workforce if the exporting firm. The measure of TBTs is the (1-year lagged) total number of concerns (HS4-destination pairs) faced by each company while tariffs are measured by the average level of tariffs of the firm (also 1-year lagged). As indicated in equation 1, all regressions include firm fixed effects and the interaction between (1-digit) sector dummies and year dummies.

Table ?? shows strong and significant results for the managerial layer, in both specifications: an additional TBT concern in one of the markets where the firm was present in the previous year, increases the share of managers by 0.3 percentage points. The fact that IV estimates are also positive and significant is reassuring as it implies that fixed effects estimates are not simply capturing entry in difficult markets (i.e. markets characterized by high TBTs) accompanied by an increase the share of managers, by firms hit by a positive (unobservable) shock. The point estimate of the TBT coefficient is three times bigger ( 1 percentage points) when estimated via IVs. This can be interpreted in light of the political economy concern discussed above. If firms that are not able to comply with new TBT (less manager-intensive firms) are more likely to lobby for raising a STCs at the WTO (implying a negative correlation between the share of managers and the number of TBT) then the OLS coefficient would be downward biased. Coherently with this argument, when the endogeneity is addressed the point estimate becomes larger.

The average increase in the share of managers comes with a significant decrease in the shares of professionals, qualified and non-qualified blue collars, suggesting a strong impact of stringent TBTs on the workforce composition of French exporters. 
Table 2: Effect of TBTs on firm layers (manufacturing sector): full sample

\begin{tabular}{|c|c|c|}
\hline & \multicolumn{2}{|c|}{ TBT } \\
\hline Share of Managers: & $\mathrm{FE}$ & $\mathrm{IV}+\mathrm{FE}$ \\
\hline TBTs & $\begin{array}{c}0.003 * * * \\
(0.000)\end{array}$ & $\begin{array}{c}0.010^{* * * *} \\
(0.001)\end{array}$ \\
\hline Tariffs & $\begin{array}{c}-0.006^{* *} \\
(0.003)\end{array}$ & $\begin{array}{c}-0.003 \\
(0.005)\end{array}$ \\
\hline
\end{tabular}

Share of Professionals:

TBTs

$\begin{array}{cc}-0.001 & -0.003^{* * *} \\ (0.000) & (0.001) \\ 0.002 & 0.002 \\ (0.004) & (0.007)\end{array}$

Share of White Collars:

TBTs

$\begin{array}{cc}0.001^{*} & -0.000 \\ (0.000) & (0.000) \\ 0.009^{* * *} & 0.010^{*} \\ (0.003) & (0.006)\end{array}$

Share of Qualified Blue Collars:

TBTs

$-0.000 \quad-0.003^{*}$

Tariffs

$(0.000) \quad(0.001)$

$-0.001 \quad 0.000$

$(0.006) \quad(0.010)$

Share of Non Qualified Blue Collars:

\begin{tabular}{lcc} 
TBTs & $-0.002^{* * *}$ & $-0.002^{*}$ \\
Tariffs & $(0.000)$ & $(0.001)$ \\
& -0.003 & -0.009 \\
& $(0.006)$ & $(0.009)$ \\
\hline Observations & 189,981 & 138,861 \\
F-stats first stage & & 159.71 \\
Number of firms & 29,990 & 22,275 \\
Firm FE\& Sector $\times$ Year FE & YES & YES \\
\hline
\end{tabular}

Source: DADS, WTO STCs and French Custom data for 1995 to 2010. 


\subsubsection{Top exporters serving more than 6 markets}

As discussed above, firms may endogenously self-select into high/low TBTs destinations. For instance, following a positive productivity shock, a firm may decide to enter a promising but costly (TBT-imposing) product-destination market. Our IV approach takes care of this concern under the assumption that the instrument is uncorrelated with firm-level shocks. Another way to (imperfectly) address this concern, is using a sub-sample of firms with an arguably homogeneous productivity level. To this end, in Table 3 we include only firms that serve more than 6 markets (the 95th percentile of the distribution of markets served by firms on average over the period), and thus arguably having a homogenously high productivity level ${ }^{20}$ In this sub-sample of firms the share of managers is on average higher than for full sample of firm used on our baseline (respectively $20 \%$ for firms with at least one TBT and $15 \%$ for firms without TBTs). All the other occupation shares are similar to the ones observed in the whole manufacturing sample. Results reported in Table 3 confirm our baseline findings, showing that, also for the most productive exporting in at least 6 markets, the presence of stringent standards at destination drives exporters towards a new organizational structure relying on a higher share of managers.

\subsection{Managerial sub-layers}

The key result so far is the positive effect of TBTs on the share of managers within the firm. However, this macro-occupational group covers a wide range of occupations (from 21 to 38 PCS French occupational code), such as directors, sales managers, engineers etc. So, testing the effect of TBTs on each sub-layer belonging to the managerial layer may help uncovering the specific channel driving the baseline results discussed above. We, therefore, split the managerial layer into 4 finer sub-layers: $(i)$ CEOs: ${ }^{21}(i i)$ sale executives; (iii) engineers and $(i v)$ other top managers (lawyers, doctors, professors, etc.) $\stackrel{22}{2}^{2}$

The share of CEOs represents on average (as full time equivalent) the $3.4 \%$ of the total employment of the firm, the sale executives the $6.8 \%$, the engineers the $4.7 \%$ and finally other top managers account for the $1.2 \%$ of total employment. In Table (4) we report the share of these categories for firms facing TBTs and other TBT-free firms. It clearly emerges that, on average, firms facing at least one TBT

\footnotetext{
${ }^{20}$ In moving from full sample to multi-destination firms (i.e. those with more than 6 destinations) the number of observations shrinks by $66 \%$ as we loose small firms with very incomplete time span.

${ }^{21}$ In the French occupation classification the $\mathrm{CS}=2$ refers to "Chef d'entreprise salarié" which is translated (maybe improperly) here as CEO. For simplicity we keep this definition of CEO in what follows with the disclaimer of imperfect translation.

${ }^{22}$ We divide the category management into the following categories: CEOs: $\mathrm{CS}=2$; Sales Executives: $\mathrm{CS}=37$; Engineers: $\mathrm{CS}=38$ and Other professionals: $\mathrm{CS}=31-33-34-35$.
} 
Table 3: Effect of TBTs on firm layers (manufacturing sector). Top exporters serving more than 6 markets.

\begin{tabular}{|c|c|c|}
\hline \multirow[b]{2}{*}{ Share of Managers: } & \multicolumn{2}{|c|}{ TBT } \\
\hline & $\mathrm{FE}$ & $\mathrm{IV}+\mathrm{FE}$ \\
\hline $\begin{array}{l}\text { TBTs } \\
\text { Tariffs }\end{array}$ & $\begin{array}{c}0.002^{* * *} \\
(0.0007) \\
-0.003 \\
(0.009)\end{array}$ & $\begin{array}{c}0.008 * * * \\
(0.001) \\
0.004 \\
(0.011)\end{array}$ \\
\hline Share of Professionals: & & \\
\hline $\begin{array}{l}\text { TBTs } \\
\text { Tariffs }\end{array}$ & $\begin{array}{c}-0.001 \\
(0.0007) \\
-0.013 \\
(0.011)\end{array}$ & $\begin{array}{c}-0.003^{* *} \\
(0.001) \\
-0.001 \\
(0.014)\end{array}$ \\
\hline Share of White Collars: & & \\
\hline $\begin{array}{l}\text { TBTs } \\
\text { Tariffs }\end{array}$ & $\begin{array}{c}0.0007 \\
(0.0006) \\
0.012 \\
(0.009)\end{array}$ & $\begin{array}{c}-0.0006 \\
(0.0009) \\
0.004 \\
(0.013)\end{array}$ \\
\hline Share of Qualified Blue Coll & & \\
\hline $\begin{array}{l}\text { TBTs } \\
\text { Tariffs }\end{array}$ & $\begin{array}{l}-0.0007 \\
(0.001) \\
-0.005 \\
(0.014)\end{array}$ & $\begin{array}{l}-0.002 \\
(0.001) \\
-0.006 \\
(0.018)\end{array}$ \\
\hline Share of Non Qualified Blue & & \\
\hline $\begin{array}{l}\text { TBTs } \\
\text { Tariffs }\end{array}$ & $\begin{array}{c}-0.001^{*} \\
(0.0008) \\
0.011 \\
(0.013)\end{array}$ & $\begin{array}{c}-0.001 \\
(0.001) \\
0.001 \\
(0.016)\end{array}$ \\
\hline $\begin{array}{l}\text { Observations } \\
\text { F-stats first stage } \\
\text { Number of firms } \\
\text { Firm FE\& Sector } \times \text { Year FE }\end{array}$ & $\begin{array}{c}64,045 \\
8,399 \\
\text { YES } \\
\end{array}$ & $\begin{array}{l}63,250 \\
169.03 \\
7,392 \\
\text { YES } \\
\end{array}$ \\
\hline
\end{tabular}

Source: DADS, WTO STCs and French Custom data for 1995 to 2010.

have higher shares of engineers. This is probably due to the fact that engineers are needed to adapt the product to a foreign technical standard.

In Table 5 we show baseline specification results on each of the occupation category composing the managerial group. From Table 5 it emerges that the positive effect we observe in Table?? on managers is mainly driven by a positive effect on both the share of engineers and the share of sales executives. Facing one additional TBT would increase the share of engineers by 0.6 percentage points and the share of sales executives by 0.3 percentage points (see IV specification in column 2). Firms facing an additional TBT have to adapt their products to meet the technical standard; and engineers are the 
Table 4: Share of managers in managerial sub-layers

\begin{tabular}{lcc}
\hline & At least one TBT & TBT-free \\
\hline Occupations (\%) & & \\
Share of CEOs & 1.7 & 2.3 \\
Share of sales executives & 6.4 & 4.3 \\
Share of engineers & 10.3 & 5.8 \\
Share of other managers & 0.3 & 0.6 \\
\hline
\end{tabular}

Source: DADS, WTO STCs and French Custom data for 1995 to 2010

most needed occupations to this end. The result on the CEOs is significant only when estimating with the IV, with TBT increasing the share of heads by 0.1 percentage point.

Table 5: Effect of TBTs on managerial sub-layers (manufacturing sector): full sample

\begin{tabular}{lcc}
\hline & \multicolumn{2}{c}{ A.TBT } \\
\cline { 2 - 3 } Share of CEOs: & FE & IV $+\mathrm{FE}$ \\
TBTs & -0.0001 & $0.001^{* * *}$ \\
& $(0.0002)$ & $(0.0004)$ \\
Tariffs & 0.001 & 0.004 \\
& $(0.001)$ & $(0.003)$ \\
Share of Sales Executives: & & \\
TBTs & $0.0009^{*}$ & $0.003^{* * *}$ \\
& $(0.0005)$ & $(0.001)$ \\
Tariffs & $-0.004^{*}$ & $-0.005^{*}$ \\
& $(0.002)$ & $(0.003)$ \\
Share of Engineers: & & \\
TBTs & & \\
Tariffs & $0.002^{* * *}$ & $0.006^{* * *}$ \\
& $(0.0005)$ & $(0.001)$ \\
Share of Other Top Managers: & $-0.003^{*}$ & -0.006 \\
TBTs & $(0.002)$ & $(0.003)$ \\
Tariffs & $-0.0002^{* *}$ & $-0.0005^{* * *}$ \\
& $(0.0001)$ & $(0.0002)$ \\
\hline Observations & -0.0003 & 0.0013 \\
F-stats first stage & $(0.0009)$ & $(0.001)$ \\
Number of firms & 189,981 & 138,861 \\
Firm FE\& Sector $\times$ Year FE & 29,990 & 159.71 \\
\hline
\end{tabular}

Source: DADS, WTO STCs and French Custom data for 1995 to 2010.

We next move to the sample of top exporters serving more than 6 markets. In this sub-sample of firms the share of engineers is on average higher than for full sample of firm used on our baseline (respectively $11 \%$ for firms with at least one TBT and $7 \%$ for firms without TBTs). All the other 
shares are similar to the ones observed in the whole manufacturing sample. Regression results reported in Table 6 confirm the findings in the full sample.

Table 6: Effect of TBTs on managerial sub-layers (manufacturing sector). Top exporters serving more than 6 markets.

\begin{tabular}{lcc}
\hline & \multicolumn{2}{c}{ TBT } \\
\cline { 2 - 3 } Share of CEOs: & $\mathrm{FE}$ & $\mathrm{IV}+\mathrm{FE}$ \\
TBTs & & \\
& & \\
Tariffs & $(0.0001$ & $0.0005^{*}$ \\
& 0.007 & $(0.0003)$ \\
& $(0.005)$ & 0.009 \\
& $0.006)$
\end{tabular}

Share of Sales Executives:

$\begin{array}{lcc}\text { TBTs } & 0.0003 & 0.004 \\ & (0.0005) & (0.001) \\ \text { Tariffs } & -0.005 & -0.0001 \\ & (0.006) & (0.007)\end{array}$

Share of Engineers:

$\begin{array}{lcc}\text { TBTs } & 0.002^{* * *} & 0.007^{* * *} \\ & (0.0006) & (0.001) \\ \text { Tariffs } & -0.004 & -0.005 \\ & (0.005) & (0.005)\end{array}$

Share of Other Top Managers:

\begin{tabular}{lcc} 
TBTs & $-0.0002^{*}$ & $-0.0005^{* * *}$ \\
Tariffs & $(0.0001)$ & $(0.0002)$ \\
& -0.001 & -0.0001 \\
& $(0.002)$ & $(0.003)$ \\
\hline Observations & 64,045 & 63,250 \\
F-stats first stage & & 169.03 \\
Number of firms & 8,399 & 7,392 \\
Firm FE\& Sector $\times$ Year FE & YES & YES \\
\hline
\end{tabular}

\subsection{The effect of TBTs on the probability to add layers (extensive margin)}

In line with the literature that explores how firms organize production in hierarchies to economize on their use of knowledge (Garicano (2000); Caliendo and Rossi-Hansberg (2012); Caliendo et al. (2018)), we also test if the increasing complexity faced by firms in export markets has an impact on the number of hierarchical layers in the organization of the firm, i.e. the extensive vertical margin of the organizational stucture. As reported in Table 1, firms with at least one TBT are very similar in terms of total number of layers to firms with no TBTs. Table 7 shows regression results both from FE and FE+IV models (along the lines of the model in equation (1)) using, in turn, three different 
dependent variables: $(i)$ the total number of layers, $(i i)$ the probability of adding a sub-layer among the top management positions (sale executives, engineers and other top managers), and the probability of adding a sub-layer among heads of enterprise (including CEOs or firm directors) ${ }_{23}^{23}$

Results reported in Table (7) show that TBTs have a positive but imprecisely estimated effect on the total number of layers (t-stat 1.7, see column 2 in Table 7). Conversely, TBT have a positive and significant effect on the probability of adding a new sub-layer at the top of the firm's hierarchy (CEOs). We can therefore conclude that the imposition of a new TBT does not change the number of layers in the firm but positively affects the probability of adding a new sub-layer at CEO level. In particular, TBTs make firms more likely to add a layer at the CEO level by 1.1 percentage points.

Table 7: Effect of TBTs on the firm organization (manufacturing sector)

\begin{tabular}{lcc}
\hline & \multicolumn{2}{c}{ TBT } \\
\cline { 2 - 3 } Total layers: & FE & IV $+\mathrm{FE}$ \\
TBTs & 0.000 & 0.012 \\
& $(0.003)$ & $(0.007)$ \\
Tariffs & 0.024 & -0.018 \\
& $(0.025)$ & $(0.04)$ \\
Probability of adding a top manager: & & \\
TBTs & -0.000 & -0.004 \\
Tariffs & $(0.001)$ & $(0.002)$ \\
& -0.022 & -0.028 \\
Probability of adding a CEO: & $(0.014)$ & $(0.023)$ \\
TBTs & & \\
Tariffs & -0.000 & $0.011^{*}$ \\
& $(0.003)$ & $(0.006)$ \\
& $0.041^{* *}$ & 0.022 \\
Observations & $(0.019)$ & $(0.03)$ \\
F-stats first stage & \multicolumn{2}{c}{} \\
Number of firms & 189,981 & 138,861 \\
Firm FE\& Sector $\times$ Year FE & 29,990 & 159.71 \\
\hline
\end{tabular}

Source: DADS, WTO STCs and French Custom data for 1995 to 2010.

\footnotetext{
${ }^{23}$ We grouped sales executives, engineers and other top-managers in a single category for the sake of table readability. The effect of TBT on each specific managerial job remains not statistically significant (results available upon request).
} 


\section{Concluding remarks}

This paper provides an empirical assessment of the effect of stringent technical standards on the workforce composition of French firms. Making use of detailed firm level matched employer-employee data with information on exports by destination country and Specific Trade Concern (STC) data released by the WTO on restrictive TBTs, we identify the effect of TBTs exploiting (unexpected) changes in bilateral TBTs between the EU and the destination countries.

We find that TBTs affect the skill composition of employment; they raise the share of managers at the expense of white collars and professionals. In particular, the share of engineers in production. This supports the idea that new stringent technical standard at destination forces the firm to adapt workforce composition by hiring workers (engineers) able to adapt the product to the new standard. 


\section{References}

Acemoglu, D., D. Autor, D. Dorn, G. H. Hanson, and B. Price (2016). Import competition and the great us employment sag of the 2000s. Journal of Labor Economics 34(S1), S141-S198.

Autor, D., D. Dorn, and G. H. Hanson (2013). The china syndrome: Local labor market effects of import competition in the united states. American Economic Review 103(6), 2121-2168.

Bas, M. and P. Bombarda (2013). Chinese Trade Reforms, Market Access and Foreign Competition: the Patterns of French Exporters. World Bank Economic Review vol. 27(1). First published online June 25, 2012.(1), 80-108.

Bernard, A. B., S. J. Redding, and P. K. Schott (2011). Multiproduct firms and trade liberalization. The Quarterly Journal of Economics 126(3), 1271-1318.

Caliendo, L., M. Mion, L. Opromolla, and E. Rossi-Hansberg (2018). Productivity and organization in Portuguese firms. Working Paper 21811, National Bureau of Economic Research.

Caliendo, L., F. Monte, and E. Rossi-Hansberg (2015). The anatomy of French production hierarchies. Journal of Political Economy 123(4), 809-852.

Caliendo, L. and E. Rossi-Hansberg (2012). The impact of trade on organization and productivity. Quarterly Journal of Economics 127(3), 1393-1467.

Chaney, T. (2008). Distorted gravity: The intensive and extensive margins of international trade. American Economic Review 98(4), 1707-0721.

Fontagné, L. and G. Orefice (2018). Let's try next door: Technical barriers to trade and multidestination firms. European Economic Review 101, 643-663.

Fontagné, L., G. Orefice, R. Piermartini, and N. Rocha (2015). Product standards and margins of trade: Firm-level evidence. Journal of International Economics 97(1), 29-44.

Fontagné, L., A. Secchi, and C. Tomasi (2018). Exporters product vectors across markets. European Economic Review 110, 150-180.

Francois, J., M. Manchin, and H. Norberg (2011). European perspectives on NTM and tariff liberalization. Technical report, ESRI Discussion Paper, Series.

Garicano, L. (2000). Hierarchies and the organization of knowledge in production. Journal of Political Economy 108(5), 874-904.

Goos, M., A. Manning, and A. Salomons (2014). Explaining job polarization: Routine-biased technological change and offshoring. American Economic Review 104 (8), 2509-2526.

Harrigan, J., A. Reshef, and F. Toubal (2016). The march of the techies: Technology, trade, and job polarization in france, 1994-2007. Technical report, National Bureau of Economic Research working paper 22110.

Keller, W. and H. Utar (2016). International trade and job polarization: Evidence at the worker-level. Technical report, National Bureau of Economic Research.

Maurin, E., M. Thoenig, and D. Thesmar (2002). Globalization and the demand for skill: an export based channel. Centre for Economic Policy Research (CEPR) working paper, 3406.

Mayer, T., M. J. Melitz, and G. I. Ottaviano (2014). Market size, competition, and the product mix of exporters. American Economic Review 104(2), 495-536.

Orefice, G. (2017). Non-tariff measures, specific trade concerns and tariff reduction. The World Economy 40(9), 1807-1835. 


\section{A Data details and additional results}

\section{A.1 Occupations}

Table A1 reports the definition of the occupation breakdown.

Table A1: Occupations

\begin{tabular}{ll}
\hline \hline Occupation & Definition \\
\hline Management & $\mathrm{CS}=2$ or $\mathrm{CS}=3$ or $\mathrm{CS}=73$ (for some years) \\
Professionals & $\mathrm{CS}=4$ or $\mathrm{CS}=74$ \\
White Collar & $\mathrm{CS}=52$ or $\mathrm{CS}=53$ or $\mathrm{CS}=54$ or $\mathrm{CS}=55$ or $\mathrm{CS}=56$ \\
Qualified Blue Collar & $\mathrm{CS}=62$ or $\mathrm{CS}=63$ or $\mathrm{CS}=64$ or $\mathrm{CS}=65$ \\
Non-qualified Blue Collar & $\mathrm{CS}=67$ or $\mathrm{CS}=68$ or $\mathrm{CS}=69$ \\
\hline \hline
\end{tabular}

